\title{
Spirochaeta dissipatitropha sp. nov., an alkaliphilic, obligately anaerobic bacterium, and emended description of the genus Spirochaeta Ehrenberg 1835
}

Correspondence

Elena V. Pikuta

Elena.Pikuta@uah.edu

Richard B. Hoover

Richard.Hoover@NASA.GOV

\author{
Elena V. Pikuta, ${ }^{1}$ Richard B. Hoover, ${ }^{1}$ Asim K. Bej, ${ }^{2}$ Damien Marsic, ${ }^{3}$ \\ William B. Whitman ${ }^{4}$ and Paul Krader $^{5}$ \\ ${ }^{1}$ NASA/NSSTC, Astrobiology Laboratory, 320 Sparkman Drive, Huntsville, AL 35805, USA \\ ${ }^{2}$ Department of Biology, University of Alabama at Birmingham, Birmingham, AL 35294, USA \\ ${ }^{3}$ Laboratory for Structural Biology, University of Alabama in Huntsville, Huntsville, \\ AL 35899, USA \\ ${ }^{4}$ Department of Microbiology, University of Georgia, Athens, GA 30602-2605, USA \\ ${ }^{5}$ American Type Culture Collection (ATCC), 10801 University Blvd, Manassas, VA 20110, USA
}

A novel obligately anaerobic, mesophilic, alkaliphilic spirochaete, strain $\mathrm{ASpC}^{\top}$, was isolated from an anaerobic sediment of alkaline, hypersaline Owens Lake in California, USA. The Gramnegative cells are motile, helical in shape and $0.23 \times 8.0-18.0 \mu \mathrm{m}$. Growth occurs within the following ranges: $13-41{ }^{\circ} \mathrm{C}$, with optimal growth at $35{ }^{\circ} \mathrm{C} ; 1-3 \%(\mathrm{w} / \mathrm{v}) \mathrm{NaCl}$, with optimal growth at $2 \%(\mathrm{w} / \mathrm{v}) \mathrm{NaCl}$; and $\mathrm{pH} 7.8-10.5$, with optimal growth at $\mathrm{pH} 10.0$. The novel isolate is strictly alkaliphilic and requires high concentrations of carbonate ions in the medium. It utilizes some sugars, some organic acids, some amino acids, Casamino acids, yeast extract and peptone. The main end products of glucose fermentation are $\mathrm{CO}_{2}$ and acetate. Strain $\mathrm{ASpC} 2{ }^{\top}$ is resistant to kanamycin and rifampicin, but sensitive to ampicillin, chloramphenicol, gentamicin and tetracycline. The DNA G+C content of the new isolate is $43.8 \mathrm{~mol} \%$, its genome size is $6 \times 10^{8} \mathrm{Da}$ and the melting temperature of its genomic DNA is $71^{\circ} \mathrm{C}$. DNA-DNA hybridization experiments demonstrated $46 \%$ similarity with the phylogenetically most closely related species, Spirochaeta asiatica Z-7591 ${ }^{\top}$. On the basis of physiological and molecular properties, the new isolate belongs taxonomically to a novel species within the genus Spirochaeta, for which the name Spirochaeta dissipatitropha sp. nov. is proposed (type strain, ASpC2 ${ }^{\top}=$ ATCC BAA-1083 ${ }^{\top}=\mathrm{JCM}$ $12856^{\top}$ ). S. dissipatitropha $A S p C 2^{\top}$ is the second strain in the genus (after Spirochaeta smaragdinae SEBR $4228^{\top}$ ) that is able to use proteolysis products as the sole energy source, and additional tests have shown that other halo-alkaliphilic spirochaetes (Spirochaeta americana, Spirochaeta alkalica and Spirochaeta africana) are also able to grow on yeast extract alone; therefore, an emended description for the genus Spirochaeta is given.
Microbiological investigations of a remnant of a vast, meromictic, alkaline, hypersaline soda lake (Owens Lake) in northern California, USA, have resulted in the isolation of several anaerobic isolates. One of them is an alkaliphilic, mesophilic bacterium that represents the recently described genus and species Anaerovirgula multivorans (Pikuta et al., 2006a). Another bacterium, freeliving spirochaete strain $\mathrm{ASpC} 2^{\mathrm{T}}$, was also isolated from

Abbreviation: $T_{\mathrm{m}}$, melting temperature.

The GenBank/EMBL/DDBJ accession number for the 16S rRNA gene sequence of strain $\mathrm{ASpC}^{\top}$ is $\mathrm{AY}^{\mathrm{S}} 995150$. the anaerobic, cellulolytic microbial community of Owens Lake (Pikuta et al., 2005).

According to its definition, the genus Spirochaeta is a group of free-living, saccharolytic, obligately or facultatively anaerobic, helical bacteria (Canale-Parola, 1977, 1984, 1992). All species of the genus Spirochaeta that have been described match these characteristics. Spirochaeta isovalerica is the only species described that, in addition to carbohydrates, is able to ferment L-leucine, L-isoleucine and L-valine, producing isovaleric, 2-methylbutyric and isobutyric acids, respectively, as the metabolic end products. However, it was shown that $S$. isovalerica requires 
a fermentable carbohydrate for growth (Harwood \& Canale-Parola, 1981a, b, 1983). The conclusion was made that fermentation of amino acids in the absence of glucose does not support measurable growth of $S$. isovalerica, but serves to generate ATP, which is utilized as a source of maintenance energy by the spirochaete when fermentable carbohydrates are not available. Much later, the species Spirochaeta smaragdinae, which ferments glycerol, fumarate, peptides and yeast extract in addition to carbohydrates, was described (Magot et al., 1997).

In our laboratory, a new spirochaete strain, $\mathrm{ASpC} 2^{\mathrm{T}}$, has been isolated from anaerobic sediments of Owens Lake in California, USA. Along with carbohydrates, this new isolate is capable of growth on yeast extract, peptone, Casamino acids, some amino acids and some organic acids. After a detailed study, it was found that the new micro-organism plays the role of a dissipotrophic secondary anaerobe in an alkaliphilic cyanobacterial community, and represents a novel species with distinguishing physiological and genetic characteristics. In this article, we present a taxonomic description of this novel spirochaete. We also provide an emended description of the genus Spirochaeta Ehrenberg 1835.

Sampling, maintenance, transportation and storage of samples were as described previously (Pikuta et al., 2002, $2006 \mathrm{a})$. The growth medium contained $\left(\mathrm{l}^{-1}\right): \mathrm{NaCl}, 10 \mathrm{~g}$; $\mathrm{Na}_{2} \mathrm{CO}_{3}, 2.76 \mathrm{~g} ; \mathrm{NaHCO}_{3}, 24.0 \mathrm{~g} ; \mathrm{KCl}, 0.2 \mathrm{~g} ; \mathrm{K}_{2} \mathrm{HPO}$, $0.2 \mathrm{~g} ; \mathrm{MgCl}_{2} .6 \mathrm{H}_{2} \mathrm{O}, 0.1 \mathrm{~g} ; \mathrm{NH}_{4} \mathrm{Cl}, 1.0 \mathrm{~g} ; \mathrm{Na}_{2} \mathrm{~S} .9 \mathrm{H}_{2} \mathrm{O}$, $0.4 \mathrm{~g}$; resazurin, $0.001 \mathrm{~g}$; yeast extract, $0.01 \mathrm{~g} ; 2 \mathrm{ml}$ vitamin solution (Wolin et al., 1963); $1 \mathrm{ml}$ trace mineral solution (Whitman et al., 1982). D-Glucose, D-mannitol or cellulose (filter paper) were used as substrates during purification of the strains. The final $\mathrm{pH}$ was adjusted to 9.5. High-purity nitrogen was used for the gas phase. Growth was recorded by measurements of $\mathrm{OD}_{595}$ using a spectrophotometer (Genesis 5; Spectronic Instruments) and by microscopy. Unless specified otherwise, the experiments were performed at $35{ }^{\circ} \mathrm{C}$, and substrates, as the sole source of carbon and energy, were added at concentrations of $5 \mathrm{~g} \mathrm{l}^{-1}$. To obtain the enrichment culture $0.5 \mathrm{~g}$ wet sediment material was injected into Hungate tubes containing growth medium with cellulose and incubated at $35{ }^{\circ} \mathrm{C}$ for 4 days. Phase-contrast microscopy of enrichment cultures on growth medium with cellulose indicated good growth of motile, helical cells. A pure culture was obtained by filtration of an enrichment culture through a sterile, $0.4 \mu \mathrm{m}$ membrane syringe filter, as described by Canale-Parola (1992). Two strains of helical cell cultures were isolated from the mud sample. The method of serial dilutions was applied four times on growth medium with D-mannitol as a substrate without yeast extract. Both strains exhibited indistinguishable characteristics of morphology, metabolism and physiology, and strain $\mathrm{ASpC} 2^{\mathrm{T}}$ was selected as the type strain of the novel species. Isolate ASpC2 ${ }^{\mathrm{T}}\left(=\mathrm{ATCC}\right.$ BAA- $\left.1083^{\mathrm{T}}=\mathrm{JCM} 12856^{\mathrm{T}}\right)$ was obtained in pure culture and was used exclusively in this study.
Growth of colonies was observed after 4 days incubation on an agar medium using the 'roll-tube' method (Hungate, 1969). The colonies were white with veil-like or cotton-ball formations, as a result of growth penetrating through the agar gel. The morphology of colonies growing on the surface of an agar medium with $10 \mu \mathrm{g}$ rifampicin $\mathrm{ml}^{-1}$ was found to be separate, white, round circles with smooth, regular edges $(0.5-2.0 \mathrm{~mm}$ in diameter) and a more densely granulated centre, with density diminishing toward the perimeter.

Cells of strain $\mathrm{ASpC}^{\mathrm{T}}$ were helical and highly motile, exhibiting a rotating, undulatory movement typical of spirochaetes. Cells were $0.20-0.25 \mu \mathrm{m}$ in diameter with a length of $8.0-18.0 \mu \mathrm{m}$, and formed regularly shaped spirals. Cells had a Gram-negative reaction and formed spheroplasts at the end of the exponential-growth phase.

All tests to check for dependence on the $\mathrm{CO}_{3}^{2-}$ and $\mathrm{Na}^{+}$ ions were carried out as described previously (Hoover et al., 2003; Pikuta et al., 2006a). Analytical procedures, optical microscopy, antibiotic-susceptibility and fatty acid analyses were also done as described previously (Hoover et al., 2003).

The novel isolate was catalase-negative and grew only under strictly anaerobic conditions. It had an obligately chemo-organoheterotrophic fermentative metabolism; it grew on media supplemented by carbohydrates without yeast extract. The doubling time under optimal conditions [ $35{ }^{\circ} \mathrm{C}, 2 \%$ (w/v) $\mathrm{NaCl}$ and $\mathrm{pH} 10.0$ ] was $5-7 \mathrm{~h}$. Some sugars, organic acids, proteolysis products and amino acids are used as substrates for growth (see species description for details).

The major fatty acid methyl esters were $\mathrm{C}_{14: 0}(20.35 \%)$, $\mathrm{C}_{16: 1}$ cis9 (11.03\%), $\mathrm{C}_{16: 0} \quad(12.72 \%), \mathrm{C}_{18: 0} \quad(5.19 \%)$, dimethylacetate $\mathrm{C}_{16: 0} \quad(23.76 \%), \mathrm{C}_{18: 0} \quad(2.03 \%)$ and summed feature 10 [a mixture of $\mathrm{C}_{18}$ unsaturated fatty acids in both cis and trans configurations] (12.99\%). Aldehydes were represented only by $\mathrm{C}_{16: 0}$ ALDE (9.24\%) (Table 1).

The DNA G+C content (mol\%) was determined as described by Mesbah et al. (1989), except that 2 U S1 nuclease (Sigma-Aldrich) was used in place of $1 \mathrm{U}$ P1 nuclease and the nuclease degradation was performed in a $20 \mathrm{mM}$ sodium acetate buffer, $\mathrm{pH}$ 5.0. Controls indicated that this modification yielded results equivalent to the original procedure. It was chosen because of the lower cost and higher availability of S1 nuclease. The total G+C content of the purified genomic DNA of strain $\mathrm{ASpC} 2^{\mathrm{T}}$ was $43.8 \pm 0.2 \mathrm{~mol} \%$ (mean $\pm \mathrm{SD}, n=12$ ). This value is the lowest so far observed within the genus Spirochaeta, but is not so different from those of Spirochaeta caldaria and Spirochaeta asiatica at 45 and $49 \mathrm{~mol} \%$, respectively (Pohlschroeder et al., 1994; Zhilina et al., 1996). Thus, the range of DNA $\mathrm{G}+\mathrm{C}$ contents within the genus Spirochaeta is truly large, $44-65 \mathrm{~mol} \%$, which is reflected below in the emended description of the genus. 
Table 1. Cellular fatty acid contents of strain $A S p C 2{ }^{\top}$ and related species

Taxa: 1, S. dissipatitropha ASpC2 ${ }^{\mathrm{T}} ; 2$, S. asiatica ATCC $700261^{\mathrm{T}}$ (Zhilina et al., 1996); 3, S. africana ATCC $700263^{\mathrm{T}}$ (Zhilina et al., 1996). All three organisms were grown using ATCC 2042 medium (http://www.atcc.org/Attachments/3203.pdf), but strain ASpC2 ${ }^{\mathrm{T}}$ had only $1 \% \mathrm{NaCl}$. Values are percentages $(\mathrm{w} / \mathrm{w})$ of total fatty acids. Abbreviations: ALDE, aldehyde; DMA, dimethyl acetate; FAME, fatty acid methyl ester.

\begin{tabular}{|lccc|}
\hline Fatty acid & $\mathbf{1}$ & $\mathbf{2}$ & $\mathbf{3}$ \\
\hline $\mathrm{C}_{14: 0}$ FAME & 20.35 & 13.79 & 6.63 \\
$\mathrm{C}_{14: 0}$ DMA & 1.24 & 2.36 & 4.99 \\
$\mathrm{C}_{16: 0}$ ALDE & 9.24 & 6.66 & 3.83 \\
$\mathrm{C}_{16: 1}$ cis 9 FAME & 11.03 & 9.64 & 6.34 \\
$\mathrm{C}_{16: 1}$ cis 11 FAME & - & 1.42 & - \\
$\mathrm{C}_{16: 0}$ FAME & 12.72 & 12.32 & 18.95 \\
$\mathrm{C}_{16: 1}$ cis 9 DMA & - & - & 1.06 \\
$\mathrm{C}_{16: 0}$ DMA & 23.76 & 21.29 & 15.31 \\
$\mathrm{C}_{18: 1}$ cis 9 FAME & - & 1.22 & 1.35 \\
Summed feature $10^{*}$ & 12.99 & 22.40 & 34.86 \\
$\mathrm{C}_{18: 0}$ FAME & 5.19 & 6.43 & 1.76 \\
$\mathrm{C}_{18: 0}$ DMA & 2.03 & 1.56 & - \\
$\mathrm{C}_{18: 1}$ cis 11 DMA & - & - & 0.80 \\
$\mathrm{C}_{20: 1}$ cis $13 /$ trans 11 & - & - & 2.37 \\
FAME & & & \\
\hline
\end{tabular}

*Summed feature 10 is $\mathrm{C}_{18: 1}$ cis $11 /$ trans $9 /$ trans6 FAME and/or an unknown fatty acid with an equivalent chain length of 17.834 .

The melting temperature $\left(T_{\mathrm{m}}\right)$ of total genomic DNA for strain ASpC2 ${ }^{\mathrm{T}}$, S. asiatica Z-7591 ${ }^{\mathrm{T}}$ and Spirochaeta africana $\mathrm{Z}-7692^{\mathrm{T}}$ was determined by using the procedure described by De Ley et al. (1970) and Gillis et al. (1970). Thirty micrograms of purified genomic DNA (Ausubel et al., 1987) from each of the three strains was denatured in $1 \times$ SSC buffer ( $\mathrm{pH}$ 7.2) by increasing the temperature of the sample from 25 to $98{ }^{\circ} \mathrm{C}$ (at a rate of $0.7-1.0{ }^{\circ} \mathrm{C} \mathrm{min}{ }^{-1}$ ); $\mathrm{OD}_{270}$ measurements were then recorded. In addition, the $T_{\mathrm{m}}$ analysis was confirmed in $1 \times$ SSC buffer $(\mathrm{pH}$ 7.0) by using SYBR Green I (Roche Applied Science) doublestranded DNA-binding dye and a Cepheid Smart Cycler instrument (Olson et al., 2007; Panicker et al., 2004). The $T_{\mathrm{m}}$ values $\left({ }^{\circ} \mathrm{C}\right)$ for DNA from each species were recorded from the fluorescent readings obtained with the SYBR Green I dye following $50 \%$ dissociation of the DNA with a steady increase in the temperature (at the rate of $\left.0.2{ }^{\circ} \mathrm{C} \mathrm{s}^{-1}\right)$. These experiments were conducted in triplicate. The $T_{\mathrm{m}}$ values were as follows (mean $\pm \mathrm{SD}, n=3$ ): strain $\mathrm{ASpC} 22^{\mathrm{T}}, 71 \pm 0.03{ }^{\circ} \mathrm{C}$; S. africana Z-7692 $2^{\mathrm{T}}, 75.4 \pm 0.06{ }^{\circ} \mathrm{C}$; S. asiatica Z-7591 ${ }^{\mathrm{T}}, 72.7 \pm 0.02{ }^{\circ} \mathrm{C}$.

The relatedness of genomic DNA between strain $\mathrm{ASpC} 2^{\mathrm{T}}$ and S. africana $\mathrm{Z}-7692^{\mathrm{T}}$ and between strain $\mathrm{ASpC} 2^{\mathrm{T}}$ and $S$. asiatica $\mathrm{Z}-7591^{\mathrm{T}}$ was determined by DNA-DNA hybridization using the DNA-reassociation kinetics method described by De Ley et al. (1970) and Johnson (1985).
Purified, sonicated genomic DNA $(75 \mu \mathrm{g})$ from each strain was added to $4 \times$ SSC buffer ( $\mathrm{pH} 7.2$ ) and $25 \%$ deionized formamide. The DNA was denatured by increasing the temperature in increments of $1{ }^{\circ} \mathrm{C} \min ^{-1}$ to $5{ }^{\circ} \mathrm{C}$ above the respective $T_{\mathrm{m}}$ values by using a Perkin Elmer UV/vis Lambda II spectrophotometer with a PTP-1 Peltier temperature programmer. The temperature was then lowered rapidly (over approx. $1.5 \mathrm{~min}$ ) to the reassociation temperature and the $A_{270}$ was recorded at $15 \mathrm{~s}$ intervals for a total of $15 \mathrm{~min}$. The initial reassociation kinetics were determined by linear-regression analysis. The experiment was conducted in triplicate. The percentage relatedness of the DNA was calculated by using the equation described by De Ley et al. (1970). All statistical analyses were performed by using Microsoft Excel software. The results showed DNA hybridization values of $58 \pm 0.8 \%$ (mean $\pm \mathrm{SD}, n=3$ ) between the genomes of strain $\mathrm{ASpC}_{2}^{\mathrm{T}}$ and S. africana Z$7692^{\mathrm{T}}$, and of $46 \pm 1.5 \%$ (mean $\pm \mathrm{SD}, n=3$ ) between the genomes of strain $\mathrm{ASpC}^{\mathrm{T}}$ and S. asiatica $\mathrm{Z}-7591^{\mathrm{T}}$.

The genome size of strain $\mathrm{ASpC} 2^{\mathrm{T}}$ was determined by using the reported genome size of $S$. asiatica $\mathrm{Z}-7591^{\mathrm{T}}$ $\left(2.1 \times 10^{9} \mathrm{Da}\right.$; Zhilina et al., 1996), DNA reassociation rates for strain $\mathrm{ASpC2}{ }^{\mathrm{T}}$ and S. asiatica $\mathrm{Z}-7591^{\mathrm{T}}$ and the equation described by Gillis et al. (1970). The calculated genome size of strain $\mathrm{ASpC}_{2}{ }^{\mathrm{T}}$ was $6 \times 10^{8} \mathrm{Da}$.

Genomic DNA was isolated by a standard phenol/chloroform extraction, followed by ethanol precipitation (Sambrook et al., 1989). The 16S rRNA gene was amplified as described previously (Hoover et al., 2003), except for the enzyme, which was Rainbow DNA polymerase (Extremozyme), and the fact that no DMSO was used in the reactions. The PCR product was purified by using a GeneClean Turbo kit (Qbiogene) and sequenced as described previously (Hoover et al., 2003). The $16 \mathrm{~S}$ rRNA gene sequence of strain $\mathrm{ASpC} 2^{\mathrm{T}}$ was aligned with those of other members of the genus Spirochaeta, after a BLAST search (Altschul et al., 1990) indicated closest similarity to members of this genus. Sequence alignment, pairwise-distance computation and phylogenetic-tree construction were performed as described previously (Pikuta et al., 2006b).

A sequence covering $1459 \mathrm{nt}$ of the $16 \mathrm{~S}$ rRNA gene of strain $\mathrm{ASpC} 2^{\mathrm{T}}$ was obtained, corresponding to positions 27-1492 of the Escherichia coli 16S rRNA gene sequence. The sequence was compared with all sequences available in GenBank and appeared to be highly similar to sequences from the spirochaete group. A phylogenetic dendrogram showing the relationship of strain $\mathrm{ASpC}^{\mathrm{T}}$ to other spirochaetes, based on 1332 common nucleotide positions, was constructed (Fig. 1). The only species that were not included were Spirochaeta plicatilis (Ehrenberg, 1835), for which no nucleotide sequence is available, and Spirochaeta thermophila (Aksenova et al., 1992), which is not among the closest relatives of strain $\mathrm{ASpC}^{\mathrm{T}}$ and for which the significantly shorter available sequence would have reduced the accuracy of the tree topology. Strain $\mathrm{ASpC} 2^{\mathrm{T}}$ appears to belong to the alkaliphilic/halophilic cluster of spirochaetes, 


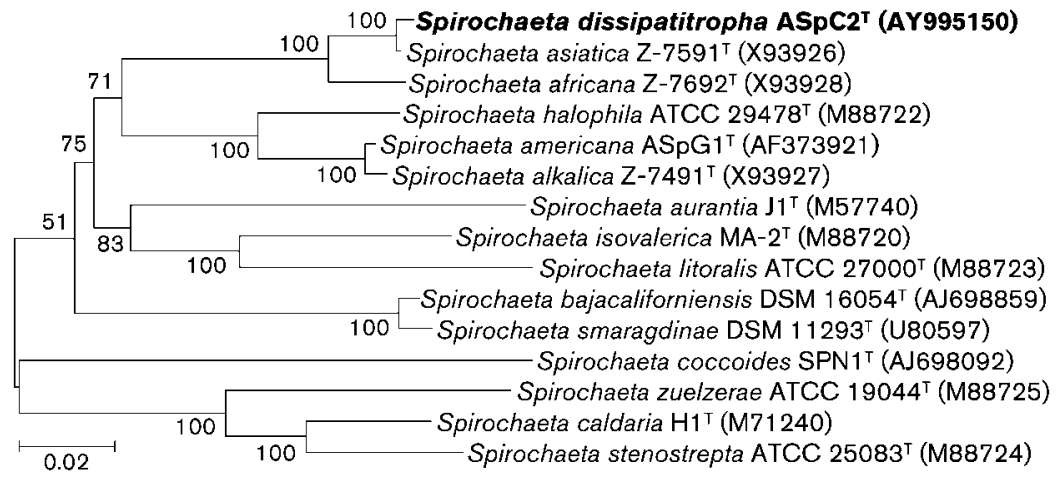

Fig. 1. Unrooted phylogenetic tree based on 16S rRNA gene sequences showing the position of strain $\mathrm{ASpC}^{\top}$ among members of the genus Spirochaeta, constructed by using the neighbour-joining method. Numbers at nodes are bootstrap percentages (1000 replicates). GenBank accession numbers are shown in parentheses. Bar, two substitutions per $100 \mathrm{nt}$.

with sequence similarities of between 87.4 and $99.5 \%$ (computed from the 1332 nucleotide positions used to construct the tree). The highest similarity was observed with S. asiatica.

Strain $\mathrm{ASpC}^{\mathrm{T}}$ was isolated from wet mud sediments beneath the red crust of a small remnant of the almost-dry Owens Lake on the eastern side of the Sierra Nevada mountains in east-central California, USA. Sedimentary deposits of this ancient lake have provided a palaeoclimatological record extending back approximately 425000 years. Owens Lake overflowed many times between 52500 and 12500 years ago (Benson et al., 1996). At the end of the last ice age (approx. 11000 years ago), meltwater from the Pleistocene glaciers filled it to a depth exceeding $70 \mathrm{~m}$ in places and the area of the lake was $>500 \mathrm{~km}^{2}$. During the silver boom of the 1870s, Owens Lake was over $10 \mathrm{~m}$ deep but, in the early 1900s, the Owens River, which fed the lake, was diverted into the Owens Valley aqueduct to provide water for Los Angeles. By 1926, the water had been almost entirely drained from the lake. Deprived of a replenishing supply, the water in the Owens Lake basin evaporated, leaving a vast hypersaline, hyperalkaline playa with the evaporite minerals trona, burkeite and halite.

The new isolate performs the function of a secondary anaerobe and behaves as a dissipotrophic micro-organism (as it utilizes the dissipation products of polymers) within the anaerobic, alkaliphilic microbial community.

On the basis of phenotypic and genotypic characteristics (shape and movement of cells, Gram-negative cell wall, fermentation of sugars, resistance to rifampicin and phylogenetic data), strain $\mathrm{ASpC}^{\mathrm{T}}$ was identified as a member of the genus Spirochaeta. Among Spirochaeta species, strain $\mathrm{ASpC} 2^{\mathrm{T}}$ was found to be only the second after S. smaragdinae DSM $11293^{\mathrm{T}}$ (Magot et al., 1997) capable of growth on proteolysis products, but the new isolate is also capable of growth on certain amino acids, with weak cell-mass yield (one to three cells per field on third transfer). Additional tests for the ability to utilize proteolysis products were conducted for all halo-alkaliphilic Spirochaeta species (S. asiatica, S. americana, S. africana and $S$. halophila). The results of these tests showed that S. americana, S. alkalica and S. africana were also able to grow with yeast extract as a sole source of carbon and energy (three transfers). Results also showed that none of the halo-alkaliphilic spirochaetes tested was able to grow on Casamino acids or peptone.

An interesting feature of this novel bacterium is its ability to utilize L- and D-ribose and L- and D-arabinose. This is the second species from Owens Lake found to have the ability to utilize sugars of alternative enantiomers. However, the other species, A. multivorans $\mathrm{SCA}^{\mathrm{T}}$, is unable to grow on D-arabinose. Subsequent investigations of enzymes and plasmids of these interesting organisms may provide additional information regarding these abilities.

Differences between the morphological, physiological and genetic characteristics of strain $\mathrm{ASpC} 2^{\mathrm{T}}$ and closely related (by phylogenetic analysis) species of the genus Spirochaeta are shown in Table 2. Strain $A S p C 2^{\mathrm{T}}$ is notably different from its phylogenetically nearest neighbour, S. asiatica Z$7591^{\mathrm{T}}$, in both $\mathrm{pH}$ and salinity characteristics and in substrates utilized. Strain $\mathrm{ASpC} 2^{\mathrm{T}}$ and S. africana Z-7692 are also different in salinity and substrates. Compared with S. alkalica $\mathrm{Z}-7491^{\mathrm{T}}$, the new isolate also exhibits differences in cell size, salinity, substrates and metabolic end products. Furthermore, the new isolate is an obligate anaerobe, whereas S. alkalica $\mathrm{Z}-7491^{\mathrm{T}}$ is a facultative anaerobe. The new spirochaete differs from S. americana $\mathrm{ASpGl}^{\mathrm{T}}$ in salinity characteristics, substrate utilization and metabolic end products ( $S$. americana $\mathrm{ASpG} 1^{\mathrm{T}}$ produces hydrogen as a major end product, but strain $\mathrm{ASpC} 2^{\mathrm{T}}$ produces hydrogen only in trace quantities). The new spirochaete differs from S. halophila $\mathrm{RS}-1^{\mathrm{T}}$ in cell size, $\mathrm{pH}$ and salinity characteristics. Their relationship with oxygen is also different. It must be pointed out that the new isolate has the most alkaline optimum $\mathrm{pH}$ for growth among all haloalkaliphilic spirochaetes. The genomic DNA G + C content of the new spirochaete is significantly different from the others (Table 2). Fatty acid analysis demonstrates the absence of branched-chain fatty acids for new isolate $\mathrm{ASpG1}^{\mathrm{T}}$, as was also observed for S. alkalica, S. africana, $S$. asiatica, S. halophila and Spirochaeta litoralis.

DNA-DNA hybridization of genomic DNA between strain $A S p C 2^{\mathrm{T}}$ and the phylogenetically most closely related species, S. asiatica $Z-7591^{\mathrm{T}}$ and S. africana $\mathrm{Z}-7692^{\mathrm{T}}$, 
Table 2. Comparative characteristics of strain $\mathrm{ASpC} 2^{\top}$ and related species of the genus Spirochaeta

Taxa: 1, S. dissipatitropha ASpC2 ${ }^{\mathrm{T}}$ (data from the present work); 2, S. asiatica Z-7591 ${ }^{\mathrm{T}}$ (Zhilina et al., 1996); 3, S. americana ASpG1 ${ }^{\mathrm{T}}$ (Hoover et al., 2003); 4, S. alkalica Z-7491 ${ }^{\mathrm{T}}$ (Zhilina et al., 1996); 5, S. africana Z-7692 ${ }^{\mathrm{T}}$ (Zhilina et al., 1996); 6, S. halophila RS- ${ }^{\mathrm{T}}$ (Greenberg \& Canale-Parola, 1976). All species use D-glucose, D-maltose, sucrose, starch and D-trehalose as substrates for growth. All species produce $\mathrm{CO}_{2}$, acetate and ethanol as products of glucose fermentation. ND, Not determined; OA, obligate anaerobe; FA, facultative anaerobe; $+/-$, substrate used/not used; $(+)$, weak growth.

\begin{tabular}{|c|c|c|c|c|c|c|}
\hline Characteristic & 1 & 2 & 3 & 4 & 5 & 6 \\
\hline Size $(\mu \mathrm{m})$ & $0.23 \times 8.0-18.0$ & $0.2-0.25 \times 15-22$ & $0.22 \times 8.0-15$ & $0.4-0.5 \times 9-18$ & $0.25-0.3 \times 15-30$ & $0.4 \times 15-30$ \\
\hline \multicolumn{7}{|l|}{$\begin{array}{l}\text { Growth conditions: } \\
\text { optimum (range) }\end{array}$} \\
\hline $\mathrm{pH}$ & $10.0(7.8-10.5)$ & $8.4-9.4(7.9-9.7)$ & $9.5(8.0-10.5)$ & $8.7-9.6(8.4-10.7)$ & $8.8-9.75(8.1-10.7)$ & 7.5 \\
\hline $\mathrm{NaCl}(\%)$ & $2(1-3)$ & 3-6 (2-8) & $3(2-12)$ & $5(3-10)$ & $5-7(3-10)$ & $3-5(0.3-7.3)$ \\
\hline Temperature $\left({ }^{\circ} \mathrm{C}\right)$ & $35(13-41)$ & $33-37(20-43)$ & $37(10-45)$ & $33-37(15-44)$ & $30-37(15-47)$ & $35-40$ \\
\hline \multicolumn{7}{|l|}{ Substrates: } \\
\hline D-Fructose & + & - & + & $(+)$ & + & + \\
\hline D-Mannitol & + & + & + & - & - & $+^{*}$ \\
\hline Lactose & - & - & + & $+^{*}$ & $+^{\star}$ & + \\
\hline D-Arabinose & + & $(+)$ & + & + & - & $+^{*}$ \\
\hline L-Arabinose & + & $+^{*}$ & + & $+^{*}$ & $-{ }^{*}$ & + \\
\hline D-Mannose & - & + & + & - & + & + \\
\hline D-Ribose & + & - & + & + & - & $+^{*}$ \\
\hline Yeast extract & + & - & + & $+^{*}$ & $+^{*}$ & - \\
\hline \multicolumn{7}{|l|}{$\begin{array}{l}\text { Products of glucose } \\
\text { fermentation: }\end{array}$} \\
\hline $\mathrm{H}_{2}$ & + & - & + & + & + & + \\
\hline Formate & ND & ND & + & ND & ND & - \\
\hline Lactate & $\mathrm{ND}$ & + & - & + & + & + \\
\hline Relationship to $\mathrm{O}_{2}$ & $\mathrm{OA}$ & OA & OA & FA & FA & $\mathrm{FA}$ \\
\hline $\begin{array}{l}\text { DNA G + C content } \\
(\mathrm{mol} \%)\end{array}$ & 43.8 & 49.2 & 58.5 & 57.1 & 56.1 & 62.0 \\
\hline Genome size (Da) & $6 \times 10^{8}$ & $2.1 \times 10^{9}$ & $2.98 \times 10^{9}$ & $2.7 \times 10^{9}$ & $2.5 \times 10^{9}$ & ND \\
\hline
\end{tabular}

${ }^{\star}$ Data from the present work.

exhibited 46 and $58 \%$ homology, respectively, allowing separation of the new isolate into a novel species. The $T_{\mathrm{m}}$ value of genomic DNA of the new isolate was $>4{ }^{\circ} \mathrm{C}$ higher than that of S. africana Z-7692 ${ }^{\mathrm{T}}$, and it was $1.7^{\circ} \mathrm{C}$ different from that of $S$. asiatica $Z-7591^{\mathrm{T}}$. Lastly, the genome size of strain $\mathrm{ASpC} 2^{\mathrm{T}}$ has been determined to be $6 \times 10^{8} \mathrm{Da}$, which is smaller than those reported for the most closely related spirochaetes, $S$. africana $\left(2.5 \times 10^{9} \mathrm{Da}\right)$ and $S$. asiatica $\left(2.1 \times 10^{9} \mathrm{Da}\right)$ (Zhilina et al., 1996).

A comparison of the phenotypic and genotypic characteristics of $\mathrm{ASpC} 2^{\mathrm{T}}$ with those of the most closely related species indicates that there are sufficient differences for strain $\mathrm{ASpC} 2^{\mathrm{T}}$ to be considered a separate species, based upon the taxonomic criteria proposed by Stackebrandt et al. (2002). The name Spirochaeta dissipatitropha sp. nov. is proposed for the novel species, with the type strain $\mathrm{ASpC} 2^{\mathrm{T}}$ $\left(=\right.$ ATCC BAA $\left.-1083^{\mathrm{T}}=\mathrm{JCM} 12856^{\mathrm{T}}\right)$.

Our study of $S$. dissipatitropha $\mathrm{ASpC}^{\mathrm{T}}$ and all haloalkaliphilic species of the genus Spirochaeta has shown that the chemotaxonomic markers in the genus description are too narrowly delimited concerning substrate utilization. $S$. dissipatitropha $\mathrm{ASpC}^{\mathrm{T}}$, as well as S. smaragdinae $\mathrm{SEBR}$ $4228^{\mathrm{T}}$, are not strictly saccharolytic species and can also utilize peptone and Casamino acids, some organic acids and, in the case of the new isolate, some amino acids. Furthermore, our studies have shown that $S$. americana $\mathrm{ASpG} 1^{\mathrm{T}}$, S. alkalica $\mathrm{Z}-7491^{\mathrm{T}}$ and S. africana $\mathrm{Z}-7692^{\mathrm{T}}$ are also able to grow on yeast extract as a sole source of carbon and energy. Based on these distinguishing chemotaxonomic markers, an emended description of the genus Spirochaeta Ehrenberg 1835 is also given. The lower boundary for the range of genomic DNA G $+\mathrm{C}$ contents is also modified within the emended description.

\section{Description of Spirochaeta dissipatitropha sp. nov.}

Spirochaeta dissipatitropha [dis.si.pa.ti.tro'pha. L. part. adj. dissipatus dissipated, dispersed; N.L. fem. adj. tropha (from Gr. adj. trophikos) nursing, tending; N.L. fem. adj. dissipatitropha tending to dissipated products, pertaining to the ability to utilize dissipated products after primary anaerobes]. 
Cells are motile and helical, with sizes of $0.23 \times 8.0$ $18.0 \mu \mathrm{m}$. Cells stain Gram-negative and have regular, unstable primary coils. Spheroplasts are formed at the end of the growth period. Alkaliphilic; cannot grow at $\mathrm{pH}$ 7.0. $\mathrm{pH}$ range for growth is 7.8-10.5, with optimum growth at $\mathrm{pH}$ 10.0. Growth is obligately dependent upon carbonate and sodium ions. Requires $\mathrm{NaCl}$ for growth: no growth occurs at $\leqslant 0.5$ or $\geqslant 3 \%(\mathrm{w} / \mathrm{v}) \mathrm{NaCl}$; optimum growth was observed at $2 \%(\mathrm{w} / \mathrm{v}) \mathrm{NaCl}$. Mesophilic; the temperature range for growth is $13-41{ }^{\circ} \mathrm{C}$, with an optimum at $35^{\circ} \mathrm{C}$. Cells can be stored frozen in liquid medium. Strictly anaerobic, catalase-negative, chemo-organoheterotrophic and dissipotrophic with fermentative metabolism. DGlucose, D-fructose, D-maltose, D-arabinose, L-arabinose, D-trehalose, D-ribose, L-ribose, starch, sucrose, D-mannitol, propionate, citrate, peptone, yeast extract, Casamino acids, L-arginine, L-isoleucine, L-methionine, L-threonine, Lhistidine, L-alanine, L-aspartic acid, L-tryptophan and Lvaline are used as substrates for growth. No growth occurs with the following substrates: acetate, lactate, pyruvate, butyrate, formate, methanol, ethanol, glycerin, betaine, chitin, pectin, L-glucose, L-fucose, L-mannose, D-mannose, lactose, glycine, L-serine, L-cysteine, L-cystine, L-phenylalanine, L-tyrosine, L-lysine, trans-4-hydroxy L-proline, Lglutamic acid, L-glutamine, L-asparagine, L-leucine, Lproline and trimethylamine. Growth on microcrystallic cellulose and filter paper occurs only on the first transfer. Major end products of glucose fermentation are $\mathrm{CO}_{2}$ and acetate; hydrogen and ethanol are minor trace products. Resistant to kanamycin and rifampicin, but sensitive to ampicillin, gentamicin, tetracycline and chloramphenicol. For the type strain, the genomic DNA G $+\mathrm{C}$ content is $43.8 \mathrm{~mol} \%$ (by HPLC), the $T_{\mathrm{m}}$ of the genomic DNA is $71{ }^{\circ} \mathrm{C}$ and the genome size is $6 \times 10^{8} \mathrm{Da}$.

The type strain, $\mathrm{ASpC} 2^{\mathrm{T}} \quad\left(=\mathrm{ATCC}\right.$ BAA $-1083^{\mathrm{T}}=\mathrm{JCM}$ $12856^{\mathrm{T}}$ ), was isolated from anaerobic mud sediments of the alkaline, hypersaline remnant of Owens Lake in eastcentral California, USA.

\section{Emended description of the genus Spirochaeta Ehrenberg 1835}

The description of the genus is as that given by CanaleParola (1984), with the following modifications. Some species are able to grow without sugars by using, as alternative substrates, some amino acids and/or proteolysis products, such as yeast extract, peptone and Casamino acids. Genomic DNA G + C content is $44-65 \mathrm{~mol} \%$.

\section{Acknowledgements}

We gratefully acknowledge the NASA JSC Astrobiology Institute for Biomarkers in Astromaterials for providing funding support for this research. Also, we are grateful to Professors J. P. Euzéby and $\mathrm{H}$. Trüper for their help with nomenclature for the novel species. We also thank the students Jasmine McDaniel and Joshua Anthony (Oakwood University) and Alisa Townsend and Melissa Guisler (University of Alabama in Huntsville) who participated in this work.

\section{References}

Aksenova, H. Y., Rainey, F. A., Janssen, P. H., Zavarzin, G. A. \& Morgan, H. W. (1992). Spirochaeta thermophila sp. nov., an obligately anaerobic, polysaccharolytic, extremely thermophilic bacterium. Int $\mathrm{J}$ Syst Bacteriol 42, 175-177.

Altschul, S. F., Gish, W., Miller, W., Myers, E. W. \& Lipman, D. J. (1990). Basic local alignment search tool. J Mol Biol 215, 403-410.

Ausubel, F. M., Brent, R., Kingston, R. E., Moore, D. D., Smith, J. G., Sideman, J. G. \& Struhl, K. (editors) (1987). Preparation and analysis of DNA. In Current Protocols in Molecular Biology, pp. 2.1.10-2.1.11. New York: Wiley.

Benson, L. V., Burdett, J. W., Kashgarian, M., Lund, S. P., Phillips, F. M. \& Rye, R. O. (1996). Climatic and hydrologic oscillations in the Owens Lake basin and adjacent Sierra Nevada, California. Science 274, 746-749.

Canale-Parola, E. (1977). Physiology and evolution of spirochetes. Bacteriol Rev 41, 181-204.

Canale-Parola, E. (1984). Genus I. Spirochaeta. In Bergey's Manual of Systematic Bacteriology, vol. 1, pp. 39-46. Edited by N. R. Krieg \& J. G. Holt. Baltimore, MD: Williams \& Wilkins.

Canale-Parola, E. (1992). Free-living saccharolytic spirochetes: the genus Spirochaeta. In The Prokaryotes, 2nd edn, vol. 4, pp. 3524-3536. Edited by A. Balows, H. G. Trüper, M. Dworkin, W. Harder \& K.-H. Schleifer. New York: Springer.

De Ley, J., Cattoir, H. \& Reynaerts, A. (1970). The quantitative measurement of DNA hybridization from renaturation rates. Eur $J$ Biochem 12, 133-142.

Ehrenberg, C. G. (1835). Dritter Beitrag zur Erkenntniss grosser Organisation in der Richtung des kleinsten Raumes. In Abhandlungen der Preussischen Akademie der Wissenschaften (Berlin) aus den Jahre 1833-1835, pp. 143-336 (in German).

Gillis, M., De Lay, J. \& De Cleene, M. (1970). The determination of molecular weight of bacterial genome DNA from renaturation rates. Eur J Biochem 12, 143-153.

Greenberg, E. P. \& Canale-Parola, E. (1976). Spirochaeta halophila sp. n., a facultative anaerobe from a high-salinity pond. Arch Microbiol 110, 185-194.

Harwood, C. S. \& Canale-Parola, E. (1981a). Branched-chain amino acid fermentation by marine spirochete: strategy for starvation survival. J Bacteriol 148, 109-116.

Harwood, C. S. \& Canale-Parola, E. (1981b). Adenosine 5'-triphosphate-yielding pathways of branched-chain amino acid fermentation by marine spirochete. J Bacteriol 148, 117-123.

Harwood, C. S. \& Canale-Parola, E. (1983). Spirochaeta isovalerica sp. nov., a marine anaerobe that forms branched-chain fatty acids as fermentation products. Int J Syst Bacteriol 33, 573-579.

Hoover, R. B., Pikuta, E. V., Bej, A. K., Marsic, D., Whitman, W. B., Tang, J. \& Krader, P. (2003). Spirochaeta americana sp. nov., a new haloalkaliphilic, obligately anaerobic spirochete isolated from soda Mono Lake in California. Int J Syst Evol Microbiol 53, 815-821.

Hungate, R. E. (1969). A roll tube method for cultivation of strict anaerobes. Methods Microbiol 3B, 117-132.

Johnson, J. L. (1985). DNA reassociation and RNA hybridisation of bacterial nucleic acids. Methods Microbiol 18, 33-74.

Magot, M., Fardeau, M.-L., Arnauld, O., Lanau, C., Olivier, B., Thomas, P. \& Patel, B. K. C. (1997). Spirochaeta smaragdinae sp. nov., a new mesophilic strictly anaerobic spirochete from an oil field. FEMS Microbiol Lett 155, 185-191.

Mesbah, M., Premachandran, U. \& Whitman, W. (1989). Precise measurement of the $\mathrm{G}+\mathrm{C}$ content of deoxyribonucleic acid by highperformance liquid chromatography. Int J Syst Bacteriol 39, 159-167. 
Olson, J. B., Harmody, D. K., Bej, A. K. \& McCarthy, P. J. (2007). Tsukamurella spongiae sp. nov., a novel actinomycete isolated from a deep-water marine sponge. Int J Syst Evol Microbiol 57, 1478-1481.

Panicker, G., Vickery, M. C. \& Bej, A. K. (2004). Multiplex PCR detection of clinical and environmental strains of Vibrio vulnificus in shellfish. Can J Microbiol 50, 911-922.

Pikuta, E. V., Detkova, E. N., Bej, A. K., Marsic, D. \& Hoover, R. B. (2002). Anaerobic halo-alkaliphilic bacterial community of athalassic hypersaline Mono Lake and Owens Lake in California. In Instruments, Methods and Missions for Astrobiology IV (Proceedings of SPIE - the International Society for Optical Engineering, vol. 4495), pp. 130144. Edited by R. B. Hoover, G. V. Levin, R. Paepe \& A. Yu. Rozanov. Bellingham, WA: SPIE.

Pikuta, E. V., Itoh, T. \& Hoover, R. B. (2005). Anaerobic decomposition of cellulose by alkaliphilic microbial community of Owens Lake, California. In Instruments, Methods and Missions for Astrobiology IX (Proceedings of SPIE - the International Society for Optical Engineering, vol. 59060, pp. 29-40. Edited by R. B. Hoover, A.Yu. Rozanov, G. V. Levin \& G. R. Gladstone. Bellingham, WA: SPIE.

Pikuta, E. V., Itoh, T., Krader, P., Tang, J., Whitman, W. B. \& Hoover, R. B. (2006a). Anaerovirgula multivorans gen. nov., sp. nov., a novel sporeforming, alkaliphilic anaerobe isolated from Owens Lake, California. Int J Syst Evol Microbiol 56, 2623-2629.

Pikuta, E. V., Hoover, R. B., Bej, A. K., Marsic, D., Whitman, W. B., Krader, P. E. \& Tang, J. (2006b). Trichococcus patagoniensis sp. nov., a facultative anaerobe that grows at $-5{ }^{\circ} \mathrm{C}$, isolated from penguin guano in Chilean Patagonia. Int J Syst Evol Microbiol 56, 20552062.

Pohlschroeder, M., Leschine, S. B. \& Canale-Parola, E. (1994). Spirochaeta caldaria sp. nov., a thermophilic bacterium that enhances cellulose degradation by Clostridium thermocellum. Arch Microbiol $161,17-24$.

Sambrook, J., Fritch, E. F. \& Maniatis, T. (1989). Molecular Cloning: a Laboratory Manual, 2nd edn. Cold Spring Harbor, NY: Cold Spring Harbor Laboratory.

Stackebrandt, E., Frederiksen, W., Garrity, G. M., Grimont, P. A. D., Kampfer, P., Maiden, M. C. J., Nesme, X., Rossello-Mora, R., Swings, J. \& other authors (2002). Report of the ad hoc committee for the re-evaluation of the species definition in bacteriology. Int $J$ Syst Evol Microbiol 52, 1043-1047.

Whitman, W. B., Ankwanda, E. \& Wolfe, R. S. (1982). Nutrition and carbon metabolism of Methanococcus voltae. J Bacteriol 149, 852-863.

Wolin, E. A., Wolin, M. J. \& Wolfe, R. S. (1963). Formation of methane by bacterial extracts. J Biol Chem 238, 2882-2886.

Zhilina, T. N., Zavarzin, G. A., Rainey, F., Kevbrin, V. V., Kostrikina, N. A. \& Lysenko, A. M. (1996). Spirochaeta alkalica sp. nov., Spirochaeta africana sp. nov., and Spirochaeta asiatica sp. nov., alkaliphilic anaerobes from the continental soda lakes in Central Asia and the East African Rift. Int J Syst Bacteriol 46, 305-312. 